\title{
Signs of disease occur in the majority of third molars in an adult population
}

\author{
Ventä, Irja
}

2017

Ventä , I , Vehkalahti , M M , Huumonen , S \& Suominen , A L 2017 , ' Signs of disease occur in the majority of third molars in an adult population ' , International Journal of Oral and Maxillofacial Surgery , vol. 46 , pp. 1635-1640 . https://doi.org/10.1016/j.ijom.2017.06.023

http://hdl.handle.net/10138/310054

https://doi.org/10.1016/j.ijom.2017.06.023

cc_by_nc_nd

acceptedVersion

Downloaded from Helda, University of Helsinki institutional repository.

This is an electronic reprint of the original article.

This reprint may differ from the original in pagination and typographic detail.

Please cite the original version. 


\section{Signs of disease occur in the majority of third molars in an adult population}

Irja Ventä ${ }^{1}$, M iira M. Vehkalahti ${ }^{1}$, Sisko Huumonen ${ }^{2}$, Anna Liisa Suominen ${ }^{3}$

${ }^{1}$ Department of Oral and M axillofacial Diseases, University of Helsinki, Helsinki, Finland 2University of Turku, Institute of Dentistry, Turku, Finland, and Department of diagnostic imaging, Turku University Hospital, Turku, Finland

${ }^{3}$ Institute of Dentistry, University of Eastern Finland, Kuopio, Finland, and Department of Oral and Maxillofacial Surgery, Kuopio University Hospital, Kuopio, Finland, and The Health Monitoring Unit, National Institute for Health and Welfare, Helsinki, Finland

\section{Address for correspondence}

Irja Ventä,

Department of Oral and Maxillofacial Diseases, Faculty of M edicine,

P.O. Box 41,

Fl-00014 University of Helsinki,

Helsinki, Finland.

Phone: +358 50 4151309, Fax: +358 9191 27265,

Email: irja.venta@helsinki.fi

Short title: Pathology of third molars in adults 


\section{ABSTRACT}

The purpose of the study was to assess clinical and radiographic signs of disease in third molars within a population that is representative of the Finnish adult population aged 30 years or older. The two-staged stratified cluster sampling method was used to catch the 6005 subjects who were examined clinically and also by panoramic radiographs. M easurements included state of impaction, dentinal caries and/or restorations, root canal fillings, periodontal pocket depths, and additional pathological findings, such as overeruption and widened follicle. Signs of disease in the third molars occurred in $47 \%$ of the adult population and in $97 \%$ of those subjects with third molars. At least one sign of disease occurred more often at $82 \%$ in erupted third molars compared to $74 \%$ of those impacted in soft tissue and $33 \%$ in bone $(P \triangleleft 0.001)$. A diseased third molar located more often in the mandible, at $60 \%$, than in the maxilla $40 \%(P \varangle 0.001)$, and was found more often at $57 \%$ in men than in women $43 \%(P \varangle$. 05$)$. It is concluded that signs of disease in third molars in the target population were more common than has been reported earlier.

Keywords: third molar; pathology; adult population; epidemiology; panoramic radiographs 


\section{INTRODUCTION}

Third molars in young adults have been widely researched and reported: especially those of patient based samples related to surgery. Less is known about third molars in non-patient populations older than 30 years. National health surveys report very few details about third molars other than the prevalence of clinically visible teeth in such adult populations.

The most comprehensive population based adult dental health surveys have until now been carried out in Germany ${ }^{1}$, the United Kingdom ${ }^{2,3}$, the United States ${ }^{4}$, South Korea5 , and Finland $d^{6,7,8}$. All these surveys include clinical oral examination but panoramic radiographs have not been taken except in the Health 2000 Survey conducted in Finland ${ }^{8}$. The prevalence of all clinically visible teeth are reported in all of these studies. However, prevalence of third molars are frequently omitted ${ }^{1,2,5}$. The third molar prevalence data are presented in two studies as follows: Clinically visible third molars are reported for $30 \%$ of dentate subjects at 30-34 years of age and for $5 \%$ of those aged 65 years and older in Finland 8 . Another study reports that the mean number of visible third molars in a US population decreased from 1.48 to 0.81 per person between 20 to 69 years of age ${ }^{4}$.

In addition to the above mentioned nationwide surveys, results on third molars obtained from smaller subsamples exist. The most comprehensive survey is the Swedish study of 693 dentate and 91 edentulous individuals from the city of Jönköping99. It includes both extraand intraoral radiographs ${ }^{9}$. In addition to the prevalence of third molars, some pathological findings are reported such as impaction rates and numbers of retained third molar roots. The percentage of at least one impacted third molar per person decreases from $37 \%$ to $12 \%$ in the mandible between the ages from 30 years to 80 years ${ }^{9}$. The corresponding 
percentages in the maxilla decrease from $27 \%$ to $12 \%$ for 30 to 80 years 9 . Similar examinations have been carried out in the same city every 10 years but third molars have been excluded from these analyses ${ }^{10}$. Impacted teeth are reported in $8 \%$ of 1418 women older than 38 years in another epidemiological Swedish study and some pathology such as widened follicle or resorption of the crown are also reported in $16 \%$ of impacted teeth ${ }^{11}$. In addition, caries and periodontal pathology in clinically visible third molars occur in subsamples of older Americans ${ }^{12}$.

Population based studies that include both clinical and radiographic findings of third molars are obviously rare. Radiography reveals conditions that cannot be found by clinical examination alone. However, comprehensive third molar data including radiographic findings have not been published before. Therefore, the aim of the present study is to identify clinical and radiographic pathological findings of third molars in the Finnish population aged 30 years and older. 


\section{MATERIAL AND METHODS}

\section{Study design and subjects}

Our present study was part of the Health 2000 Survey (BRIF8901, Bioresource Research Impact Factor) that was organized by the National Institute for Health and Welfare (THL) in Finland ${ }^{13}$. The survey was carried out during the years 2000 and 2001 and represented the whole Finnish adult population ${ }^{14}$. The two-staged stratified cluster sampling design and methodology of the survey was presented earlier ${ }^{15}$. The main sample included 8028 subjects aged 30 years or older of whom 6335 participated in clinical oral examination during which panoramic radiographs were obtained from 6115 participants (Figure 1). The present study is based on 6005 participants that were examined both clinically and radiographically as 110 radiographs were excluded due to inadequate quality around at least one of the third molar areas. Radiographically examined sample accounted for $95 \%$ of the participants in clinical oral examination. The year of birth of the subjects ranged from 1903 to 1970 (age range 3097 years). The mean age of the 6005 participants was $52.5( \pm 14.6)$ years and $46 \%$ of whom were men and $54 \%$ were women.

\section{Clinical examination}

The field teams that carried out the clinical oral examinations consisted of a dentist and an assistant nurse. The examiners were trained and calibrated before the study and regularly during the study to standardize study evaluation procedures ${ }^{8}$. Presence and identification of teeth, dentinal caries and restorations were recorded for each tooth. The depth of periodontal pockets of second molars adjacent to third molars was measured and categorized as follows: less than $4 \mathrm{~mm}$, between 4 to $6 \mathrm{~mm}$, and more than $6 \mathrm{~mm}$. The 
pockets were measured at four points around the tooth and the deepest measurement was recorded.

\section{Radiographic examination}

Participation in the radiographic examination was voluntary. Panoramic radiographs were taken with Planmeca 2002 CC Proline (Planmeca, Helsinki, Finland) equipment using 58 to 68 $\mathrm{kV}$ and 4 to $10 \mathrm{~mA}$ depending on the size of the subject. Images were examined using the softwares of Dimaxis (Plandent, Helsinki, Finland), and more recently in this study using Romexis version 3.6.0.R (Planmeca, Helsinki, Finland). M easuring tools of the Romexis software were utilized for determining the width of follicles when needed.

Panoramic radiographs were re-examined for this study by the first author in relation to third molar findings and included the following: the state of impaction, the presence of dentinal caries or fillings, the presence of root canal fillings, and any additional pathologic findings. The state of impaction was classified as follows: 1) erupted (cemento-enamel junction mesially and distally above the bone surface), 2) impacted in soft-tissue (less than two thirds of the crown covered by bone), and 3) impacted in bone (two thirds or more of the crown covered by bone) ${ }^{16}$. The presence of caries was recorded when caries had been diagnosed clinically or could be diagnosed from the radiograph or when there was an existing restoration. A tooth was recorded as having a root canal filling when one or more canals were filled. Additional pathologic findings by tooth included the following: retained/residual root, tumor, pericoronitis (width of follicle 3-5mm), cyst (width of follicle more than $5 \mathrm{~mm}$ ), supernumerary tooth in the third molar region, periapical radiolucent lesion, overeruption, bone loss (horizontally or vertically extending at least to the middle 
third of the root), rudimental size of the tooth, resorption of the crown, sclerosis of the bone around the tooth, and mandibular fracture through the third molar. Only one if any of these additional pathologic findings per tooth was recorded in the order presented above.

When examining the panoramic radiographs, 2879 images (47\%) of radiographs were examined a second time after six weeks before proceeding to the rest of the radiographs. This was done as training for the harmonization of interpretations, and especially to recognize second and third molars in a partially edentulous dentition. After examination of all panoramic radiographs, $610(10 \%)$ of them were randomly selected and re-examined to assess the intra-examiner reliability of the measurements. The agreement was $93 \%$ for the recognition of third molars, $97 \%$ for state of impaction, and $92 \%$ for pathological findings. Kappa-values were 0.882 for recognition, and ranged from 0.882 to 0.945 for impaction, and from 0.877 to 1.000 for pathological findings (all excellent agreement, $P<<0.001$ for all).

It was realized that the identification of second and third molars was not always consistent between the radiographic examination and the original clinical recordings. The adjustment of identification findings was done by opening each panoramic radiograph once more. The clinical recordings of the first, second and third molar in the SPSS file were compared with the panoramic radiographs in respect to caries and the depth of periodontal pockets. Clinical recordings of the tooth were then adjusted for the corresponding tooth and the radiographic identification of teeth was kept unchanged. 


\section{Statistical analyses}

Results were based on third molars and retained dental third molar roots were excluded. According to International Classification of Diseases ${ }^{17}$ it would also be justified to include impactions and residual roots to get the total disease burden, and therefore, retained roots were included in the latter part of the analyses. Descriptive statistics were computed with SPSS Statistics version 24. Categorical differences in frequencies between genders, jaws, and states of impaction were tested using the Chi-squared test with statistical significance set at $P \varangle 0$.05. Results were presented categorized into age groups as follows: $30-44$ years, $45-54$ years, 55-64 years, 65-74 years, and 75 years and older. At the end of the analysis, SAS Callable SUDAAN software version 11.0.1. was used to account for the complex sampling method and to get weighted distributions of diseased third molars representative of all Finns aged 30 years and older.

\section{Ethical considerations}

The study was carried out after receiving permission from the National Institute for Health and Welfare. Researchers were blinded to the identity of the subjects by using a unique six digit number for each study participant. Ethical approvals for the examinations in 2000 were obtained from the Ethics committee of the National Public Health Institute and the Ethics committee of Epidemiology and National Health in the Hospital District of Helsinki and Uusimaa (HUS). A safety license was granted by the Radiation and Nuclear Safety Authority (STUK) of Finland (No.: 4969/L1/00). 


\section{RESULTS}

At least one, third molar or a remnant of it was found in $47 \%$ of the subjects and this occurred more often in men than in women ( $55 \%$ vs. $40 \% ; X^{2}=147.46 ; d f=1 ; P \varangle 0.001$ ), and more often in the mandible than the maxilla ( $57 \%$ vs. $\left.43 \% ; X^{2}=254.56 ; d f=1 ; P \varangle 0.001\right)$. The total number of third molars found in this study was 5665 . The distribution of these teeth according to the state of impaction showed that most of the teeth had erupted, and a little more than half of the third molars were found in the youngest age group (Table 1).

The most common sign of disease of the third molars was caries and/ or restoration with a prevalence of $68 \%$ of erupted third molars (Table 2). Caries and/or restoration were detected more often in erupted third molars than in those impacted in the soft tissue $(68 \%$ vs. $\left.48 \% ; X^{2}=128.37 ; d f=1 ; P \varangle 0.001\right)$. A total of $98(2.2 \%)$ root canal fillings were found in erupted and soft tissue impacted third molars, which amounts to $3 \%$ of erupted and $0.4 \%$ of soft tissue impacted teeth.

The second most common sign of disease was deepened periodontal pocket $(\geq 4 \mathrm{~mm})$ of the second molar that was immediately adjacent to a third molar (Table 3). A deepened pocket was more often found adjacent to an erupted third molar than to a third molar impacted in bone (40\% vs. $\left.33 \% ; X^{2}=16.31 ; d f=1 ; P \varangle 0.001\right)$.

Additional pathological findings (tumor, pericoronitis, cyst etc.) were more often found in third molars that had impacted in soft tissue compared to erupted third molars ( $26 \%$ vs. $21 \% ; X^{2}=7.30 ; d f=1 ; P \varangle 0.01$ ), or compared to those impacted in bone ( $26 \%$ vs. $7 \%$; $X^{2}=145.85 ; d f=1 ; P \varangle 0.001$ ) (Table 4). The most common prevalence for additional 
pathological findings of erupted third molars were overeruption $13 \%$, followed by a bone defect $7 \%$, and periapical lesion $1 \%$ (Figure $2 \mathrm{~A}$ ). The most common prevalence for additional finding in third molars impacted in soft tissue were pericoronitis $14 \%$, followed by overeruption $8 \%$, and cyst 2\% (Figure 2B). The most common prevalence for additional findings in third molars impacted in the bone were pericoronitis 3\%, followed by resorption of the crown $2 \%$, and supernumerary tooth $1 \%$ (Figure $2 \mathrm{C}$ ).

When the results of caries and/or restoration, deepened periodontal pockets of the second molars adjacent to third molars, and additional pathological findings were all combined, it was found that 3996 of the 5665 teeth $(71 \%)$ had at least one sign of these diseases. The corresponding prevalence was $61 \%$ in the youngest age group and $94 \%$ in the oldest. At least one sign of disease was found more often in erupted third molars than in those impacted in the soft tissue ( $82 \%$ vs. $74 \% ; X^{2}=35.75 ; d f=1 ; P \varangle 0.001$ ), and more often in soft tissue impacted third molars than in those impacted in bone ( $74 \%$ vs. $33 \% ; X^{2}=333.45 ; d f=1$; $P \varangle 0.001)$.

When impactions and residual roots findings were added to the total disease burden, it was found that $89 \%$ of third molars were associated with at least one sign of disease ( $n=5665$ teeth +268 root remnants $=5933$ ) (Figure 3). A diseased third molar was found to be located more often in the mandible than in the maxilla ( $60 \%$ vs. $40 \% ; X^{2}=107.01 ; d f=1 ; P \varangle 0.001$ ), and it was found more often in men than in women ( $57 \%$ vs. $\left.43 \% ; X^{2}=3.87 ; d f=1 ; P \varangle 0.05\right)$. The percentage of diseased third molars in men was smaller than in women in the 75 years and older age group, but the Chi-squared test could not verify this difference as expected value was less than five in two cells. 
From our total of 6005 subjects (with 5933 third molars and root remnants), 20\% had one, $14 \%$ had two, $8 \%$ had three, and $5 \%$ had four third molars with signs of disease. The weighted distributions were as follows: Signs of disease in the third molars occurred in $47 \%$ of the adult population and in $97 \%$ of those subjects with third molars. 


\section{DISCUSSION}

The key result of this study was that in the target population almost all of the third molars that had either erupted or impacted, were hampered by at least one sign of dental disease or pathologic condition. Our results suggest surprisingly larger numbers of pathological findings than had hitherto been published. This discrepancy could be explained by the fact that the earlier studies had focused mainly on impacted teeth or studied smaller subpopulations.

Results from nationally representative population surveys are not available for comparison of signs of disease. However, Stanley et a ${ }^{18}$ who studied panoramic radiographs of 3702 impacted third molars concluded that some type of pathological change can be expected in $12 \%$ of subjects with impacted third molars and in $1.8 \%$ of the general population. Another panoramic radiographic investigation of 1211 impacted third molars found pathological changes in $5.2 \%$ of maxillary and $8 \%$ of mandibular third molars ${ }^{19}$. The prevalence of pathological changes found in these two studies are about the same as we found in the present study for additional pathological findings.

When caries and periodontal pathology are taken into account and erupted third molars are also included, the prevalence of reported pathology is higher. Panoramic radiographs obtained by a dental school indicated that the most common pathology of third molars is caries in those patients between the ages of 13 to 75 years $^{20}$. However, that study included only $8 \%$ of subjects older than 30 years, whereas our study entirely focused on subjects older than 30 years. According to a radiographic study on 3050 impacted mandibular third molars in patients aged $18-60$ years, $26.5 \%$ of the teeth were affected either by caries of the 
second or third molar, or bone loss either distally or mesially of the third molar ${ }^{21}$. Among middle-aged and older Americans with clinically visible third molars, $78 \%$ of the subjects had an occlusal caries experience and $89 \%$ had periodontal pathology in their third molars ${ }^{12}$. The $78 \%$ and $89 \%$ values are similar to our findings for the age group of 65 years and older.

It should be noted that the prevalence of pathological findings in third molars indicated for removal are not similar to the findings in the whole population. The most frequent indication for removal reported in 666 patients aged 15-80 years was pericoronitis with the prevalence of $64 \%$, followed by caries at $31 \%^{22}$. In addition, two thirds of those third molars with pathologic conditions were partially covered by soft tissue. Pericoronitis in our study population had a prevalence of only $14 \%$ or less depending on the state of impaction. Furthermore, the proportion of third molars impacted in soft tissue in our data was only $16 \%$, which indicates that such teeth are poor survivors in the population: they either erupt or will be extracted. According to a follow-up study of partially erupted third molars, $33 \%$ of the teeth erupted and $66 \%$ were extracted by the age of 38 years $^{23}$.

It is difficult to recognize the third molar and to discern third and second molars in older persons with only a few erupted teeth remaining. The intra-examiner agreement for recognition of third molars in our study was excellent (Kappa-value 0.882, $P<<0.001$ ), which may have been influenced by several factors. First, our clinical examinations were carried out by trained dentists whose approaches to interpreting the findings had been harmonized by special training. Second, panoramic radiographs were initially examined by three trained specialists in oral and maxillofacial radiology. Third, panoramic radiographs in the present study were re-examined, which referred to earlier input data on recognition. The decisive 
radiographic features in recognition were anatomy, size and inclination of the tooth, curvature of roots, location of the apex, possible outline of recently removed tooth, and symmetry with the other side of the jaw.

The eruptional stage of a third molar should be taken into account when assessing the clinical relevance of our results. Our sample, which is representative of the Finnish population aged 30 years and older found that erupted third molars were most often associated with at least one sign of dental disease (82\%). Unexpectedly, third molars that had impacted in the soft tissue showed fewer signs of disease (74\%) than their erupted counterparts, and the teeth that had impacted in the bone had the least number of signs (33\%). This may imply that it is easy to assess a clear indication for removal of erupted third molars and third molars that are impacted in the soft tissue. However, the probability of pathology in the third molars that had impacted in bone was considerably low and consequently, the recommendation to remove them would not be as urgent as for the other eruptional stages. In addition, the results also emphasize that erupted third molars must especially be kept clean by self-care in order to combat against the most common dental diseases, i.e. caries and periodontal pathology.

Several earlier studies have focused on impacted third molars and associated pathology and found that pathological findings are rather rare. Our study showed that in the population pathological findings were indeed rare in third molars impacted in the bone, but were considerably more common in erupted third molars and in those third molars that had impacted in the soft tissue. It is concluded, that signs of disease in almost all of the third 
molars, either erupted or impacted can be diagnosed, in the population. However, not all of our observed signs of disease need treatment.

\section{Acknowledgements}

We acknowledge Planmeca Oy (Helsinki, Finland) for placing the digital panoramic X-ray apparatus and software at our disposal. Our study is part of the Health 2000 Health examination survey that was organized by the National Public Health Institute of Finland and was partly supported by the Finnish Dental Society Apollonia and the Finnish Dental Association. We thank DDS M ika M attila and DDS, PhD Kari Soikkonen for participation in the interpretation of the radiographs.

\section{Declarations}

Funding: Field trials were funded by the National Institute for Health and Welfare (THL) in Finland, the Finnish Dental Society Apollonia, and the Finnish Dental Association.

Competing Interests: None.

Ethical Approval: Ethical approvals were obtained from the Ethics Committee of the National Public Health Institute (now THL) and the Ethics Committee of Epidemiology and National Health in the Hospital District of Helsinki and Uusimaa (HUS). Safety license was granted by Radiation and Nuclear Safety Authority (STUK) in Finland (No.: 4969/L1/00). Patient Consent: Informed subjects participated in the study on an entirely voluntary basis. 


\section{REFERENCES}

1. Schiffner U, Hoffmann T, Kerschbaum T, Micheelis W. Oral health in German children, adolescents, adults and senior citizens in 2005. Community Dent Health 2009: 26: 1822.

2. Fuller E, Steele J, Watt R, Nuttall N. 1: Oral health and function - a report from the Adult Dental Health Survey 2009. The NHS Information Centre. The Health and Social Care Information Centre 2011. http://www.hscic.gov.uk/catalogue/PUB01086/aduldent-heal-surv-summ-them-the1-2009-rep3.pdf. [Accessibility verified Jan 23, 2017].

3. Steele JG, Treasure ET, O'Sullivan I, M orris J, M urray JJ. Adult Dental Health Survey 2009: transformations in British oral health 1968-2009. Br Dent J 2012: 213(10): 523527.

4. Magraw CBL, M oss KL, Fisher EL, Offenbacher S, White RP Jr. Prevalence of visible third molars in the United States population: How many individuals have third molars? J Oral Maxillofac Surg 2016: 74: 13-17.

5. Kim H-N, Ha T-G, Kim M-J, Jun E-J, Jeong S-H, Kim J-B. Factors related to number of present teeth in Korean elderly adults aged 55-84 years. Int J Dent Hygiene 2016: 14: 151-158.

6. Vehkalahti M, Paunio IK, Nyyssönen V, Aromaa A (eds.). Oral Health in the adult Finnish population and associated factors. (Abstract in English). Publications of the Social Insurance Institution AL:34. Helsinki and Turku, Finland 1991: 237-246.

7. National Institute for Health and Wellfare. Mini-Finland Health Survey. National Institute for Health and Welfare Finland 2016. https://www.thl.fi/en/web/thlfien/research-and-expertwork/population-studies/finnish-mobile-clinic/mini-finlandhealth-survey. [Accessibility verified Jan 23, 2017]. 
8. Suominen-Taipale L, Nordblad A, Vehkalahti M, Aromaa A (eds). Oral health in the Finnish adult population. Health 2000 Survey. Publications of the National Public Health Institute B25/2008, Helsinki Finland 2008.

http://www.julkari.fi/handle/10024/103030. [Accessibility verified Jan 23, 2017].

9. Hugoson A, Kugelberg CF. The prevalence of third molars in a Swedish population. An epiodemiological study. Community Dent Health 1988: 5: 121-138.

10. Norderyd O, Koch G, Papias A, Köhler A, Helkimo A, Brahm CO, Lindmark U, Lindfors N, M attson A, Rolander B, Ullbro C, Gerdin E, Frisk F. Oral health of individuals aged 3-80 years in Jönköping, Sweden during 40 years (1973-2013). Swed Dent J 2015: 39(2): 69-86.

11. Ahlqwist M, Gröndahl H-G. Prevalence of impacted teeth and associated pathology in middle-aged and older Swedish women. Community Dent Oral Epidemiol 1991: 19: 116-119.

12. Garaas R, M oss K, Fisher E, Wilson G, Offenbacher S, Beck J, White R Jr. Prevalence of visible third molars with caries experience or periodontal pathology in middle-aged and older Americans. J Oral M axillofac Surg 2011: 69: 463-470.

13. National Institute for Health and Welfare. Health 2000 and 2011 Surveys. National Institute for Health and Welfare, Finland 2016. https://www.thl.fi/en/web/thlfien/topics/information-packages/thl-biobank/researchers/sample-collections/health2000-and-2011. [Accessibility verified Jan 23, 2017].

14. Aromaa A, Koskinen S (eds). Health and functional capacity in Finland. Baseline results of the Health 2000 Health examination survey. Publications of the National Public Health Institute B12/2004. Helsinki, Finland 2004. 
http://www.julkari.fi/bitstream/handle/10024/78534/KTLB12-2004.pdf?sequence=1. [Accessibility verified Jan 23, 2017].

15. Heistaro S. M ethodology report. Health 2000 Survey. Publications of the National Public Health Institute B 26/2008. National Public Health Institute. Helsinki, Finland 2008.

http://www.julkari.fi/bitstream/handle/10024/78185/2008b26.pdf?sequence=1. [Accessibility verified Jan 23, 2017].

16. Nunn ME, Fish MD, Garcia RI, Kaye EK, Figueroa R, Gohel A, Ito M, Lee HJ, Williams $\mathrm{DE}, \mathrm{M}$ iyamoto T. Retained asymptomatic third molars and risk for second molar pathology. J Dent Res 2013: 92(12): 1095-1099.

17. World Health Organization. International Statistical Classification of Diseases and Related Health Problems 10th Revision (ICD-10)-WHO Version for; 2016. Chapter XI. Diseases of the digestive system. Diseases of oral cavity, salivary glands and jaws. http://apps.who.int/classifications/icd10/browse/2016/en\#/K00-K14. [Accessibility verified Jan 23, 2017].

18. Stanley HR, Alattar M, Collett WK, Stringfellow HR Jr, Spiegel EH. Pathological sequelae of "neglected" impacted third molars. J Oral Pathol 1988: 17: 113-117.

19. Eliasson S, Heimdahl A, Nordenram A. Pathological changes related to long-term impaction of third molars. A radiographic study. Int J Oral Maxillofac Surg 1989: 18: 210-212.

20. Linden van der W, Cleaton-Jones P, Lownie M. Diseases and lesions associated with third molars. Review of 1001 cases. Oral Surg Oral M ed Oral Pathol Oral Radiol Endod 1995: 79: 142-145. 
21. Polat HB, Özan F, Kara I, Özdemir H, Ay S. Prevalence of commonly found pathoses associated with mandibular impacted third molars based on panoramic radiographs in Turkish population. Oral Surg Oral M ed Oral Pathol Oral Radiol Endod 2008: 105: e41-e47.

22. Knutsson K, Brehmer B, Lysell L, Rohlin M. Pathoses associated to third molars subjected to removal. Oral Surg Oral M ed Oral Pathol Oral Radiol Endod 1996: 82: 1017.

23. Ventä I, Ylipaavalniemi P, Turtola L. Clinical outcome of third molars in adults followed during 18 years. J Oral M axillofac Surg 2004: 62: 182-185. 


\section{Tables}

Table 1. Distribution (\%) of the 5665 third molars according to eruptional stage, by subjects' age.

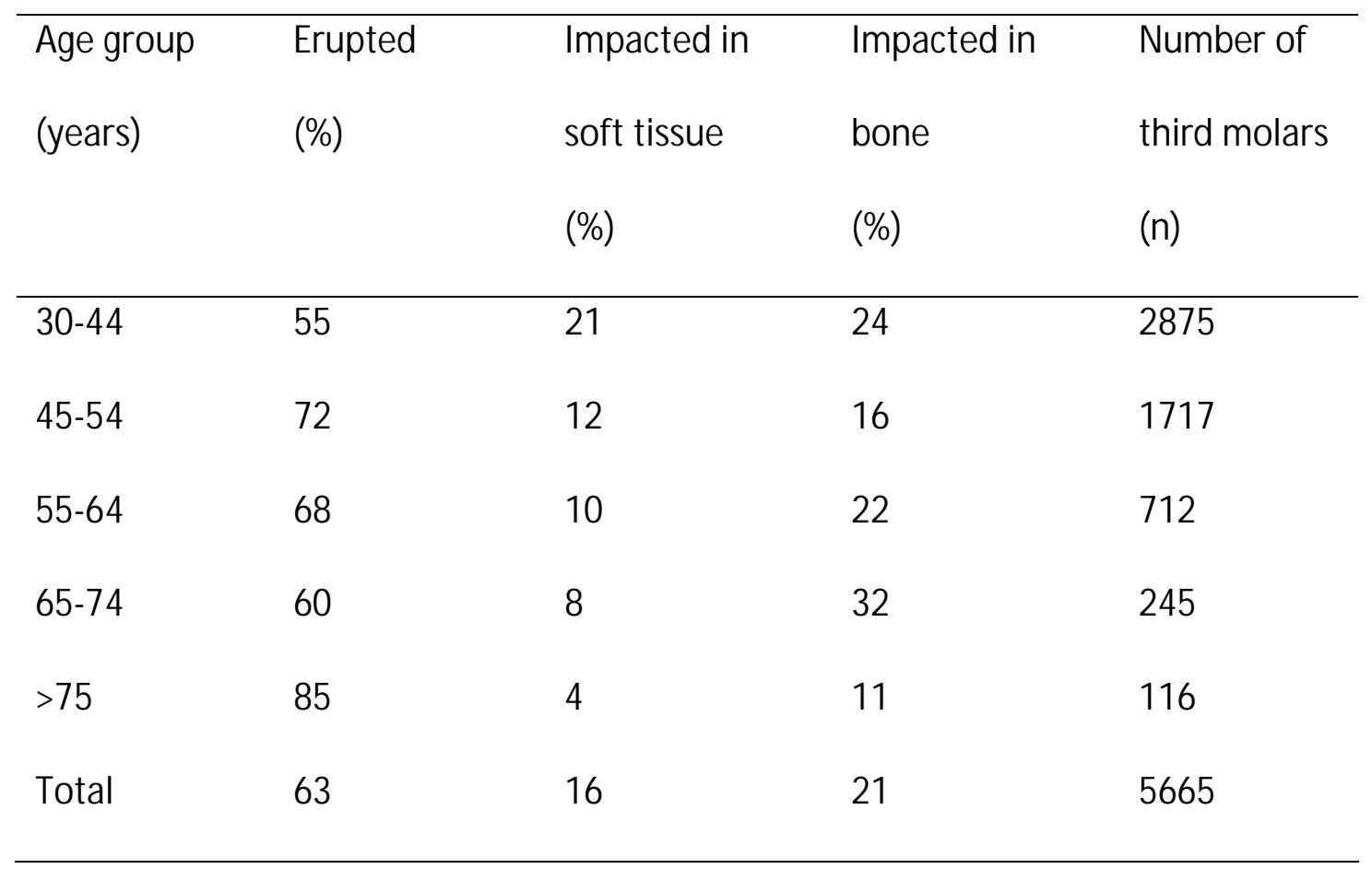


Table 2. Percentages of third molars with present caries and/or existing restoration for erupted and soft tissue impacted third molars separately, by subjects' age. Findings related to bony impactions were excluded due to the small number of caries and/or restorations ( $n=9$ teeth).

Present caries and/or existing restoration (\%)

\begin{tabular}{llll}
\hline $\begin{array}{l}\text { Age group } \\
\text { (years) }\end{array}$ & $\begin{array}{l}\text { Erupted } \\
(\mathrm{n}=3559 \text { teeth })\end{array}$ & $\begin{array}{l}\text { Impacted in soft } \\
\text { tissue } \\
(\mathrm{n}=891 \text { teeth) }\end{array}$ & P-value* \\
\hline $30-44$ & 54 & 39 & $\mathrm{P} \varangle 0.001$ \\
$45-54$ & 77 & 63 & $\mathrm{P} \varangle 0.001$ \\
$55-64$ & 84 & 73 & $\mathrm{P} \varangle 0.05$ \\
$65-74$ & 86 & 75 & $\mathrm{n} . \mathrm{s}$. \\
$>75$ & 91 & 80 & $\mathrm{n} . \mathrm{s}$. \\
Total & 68 & 48 & $\mathrm{P} \varangle 0.001$ \\
\hline *Chi-squared test, df=1. n.s. =not significant. & &
\end{tabular}


Table 3. Percentages of second molars with deepened periodontal pocket $(\geq 4 \mathrm{~mm})$ adjacent to a third molar ( $n=4435)$ in each age group and in relation to state of impaction of a third molar.

\begin{tabular}{|c|c|c|c|c|}
\hline & Neighboring $2^{\text {nd }}$ & molar (\%) with o & epened pocket ( $\geq$ & $4 \mathrm{~mm})$ \\
\hline $\begin{array}{l}\text { Age group } \\
\text { (years) }\end{array}$ & $\begin{array}{l}\text { Erupted } \\
\text { ( } n=2579 \text { teeth) }\end{array}$ & $\begin{array}{l}\text { Impacted in } \\
\text { soft tissue } \\
\text { ( } n=775 \text { teeth) }\end{array}$ & $\begin{array}{l}\text { Impacted in } \\
\text { bone } \\
\text { (n=1081 teeth) }\end{array}$ & P-value* \\
\hline $30-44$ & 32 & 31 & 26 & $P \varangle 0.05$ \\
\hline $45-54$ & 46 & 51 & 40 & n.s. \\
\hline $55-64$ & 49 & 51 & 47 & n.s. \\
\hline $65-74$ & 75 & 60 & 53 & n.s. \\
\hline$>75$ & 67 & n.a. & n.a. & - \\
\hline Total & 40 & 36 & 33 & $P \varangle 0.001$ \\
\hline
\end{tabular}


Table 4. Percentages of additional pathological findings of the 5665 third molars in each age group and in relation to state of impaction of a third molar. Included findings: tumor, pericoronitis, cyst, supernumerary tooth, periapical lesion, overeruption, bone loss, rudimental size, resorption, sclerosis, or mandibular fracture.

Additional pathological findings of third molars (\%)

\begin{tabular}{lllll}
\hline $\begin{array}{l}\text { Age group } \\
\text { (years) }\end{array}$ & $\begin{array}{l}\text { Erupted } \\
(\mathrm{n}=3559\end{array}$ & $\begin{array}{l}\text { Impacted in } \\
\text { soft tissue } \\
\text { teeth })\end{array}$ & $\begin{array}{l}\text { Impacted in } \\
\text { bone }\end{array}$ & P-value* \\
& & & & \\
& & & & \\
& 19 & 2691 teeth $)$ & $(\mathrm{n}=1215$ \\
teeth $)$ & \\
\hline $30-44$ & 21 & 25 & 5 & $P \varangle 0.001$ \\
$45-54$ & 26 & 26 & 15 & $P \varangle 0.001$ \\
$55-64$ & 32 & n.a. & n.a. & - \\
$65-74$ & 33 & n.a. & n.a. & - \\
$>75$ & 21 & 26 & 7 & $P \varangle 0.001$ \\
Total & & & & \\
\hline
\end{tabular}

*Chi-squared test, $\mathrm{df}=2$. n.a. $=$ not applicable due to the small number of teeth. 


\section{Captions to illustrations}

Figure 1. Flow diagram of the numbers of participants and third molars in the study.

Figure 2. Signs of disease in third molars in cropped panoramic radiographs. A. Erupted and filled right mandibular third molar with bone defect extending to the middle third of the root in a 56-year-old man. Pocket depth of adjacent second molar was deepened (4-6mm). Upper right third molar had erupted and was filled and with a neighboring second molar with deepened periodontal pocket (4-6mm). B. Widened follicle of the right mandibular third molar with over-eruption and impacted in soft tissue in a 42-year-old woman. Neighboring second molar with deepened periodontal pocket (4-6mm). C. Right mandibular third molar impacted in bone with resorption of the crown in a 75-year-old man.

Figure 3. Occurrence of at least one of the following signs of disease in a third molar, by subjects' age: impacted in soft tissue or in bone, caries and/or restoration, deepened periodontal pocket of neighboring second molar, and additional pathological findings including residual roots. ( $\mathrm{N}=5665$ third molars +268 residual roots $=5933$ teeth). The dashed line indicates the percentages of diseased third molars in men, and the solid line indicates the percentages of diseased third molars in the maxilla. 


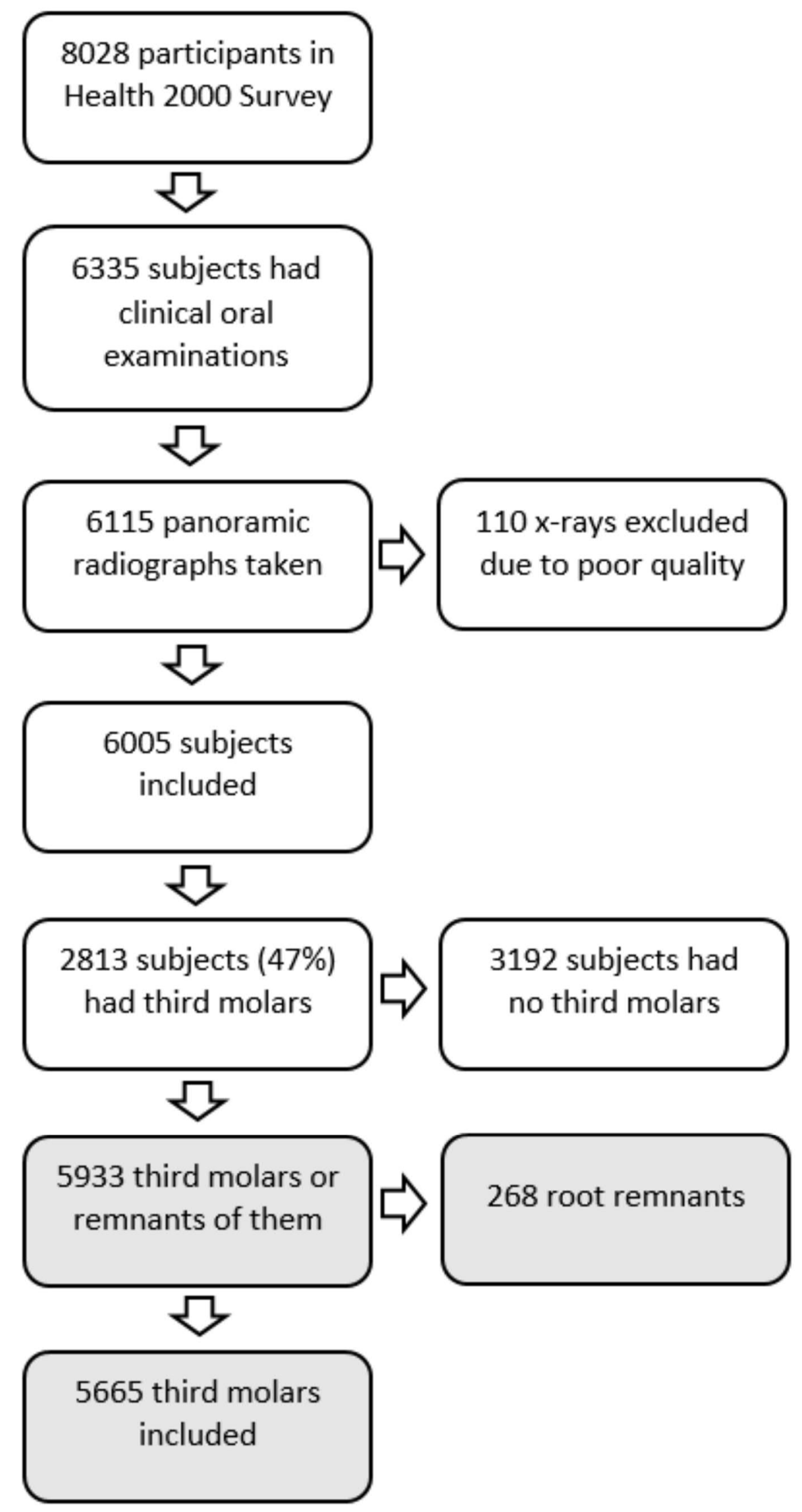

Figure 1. 

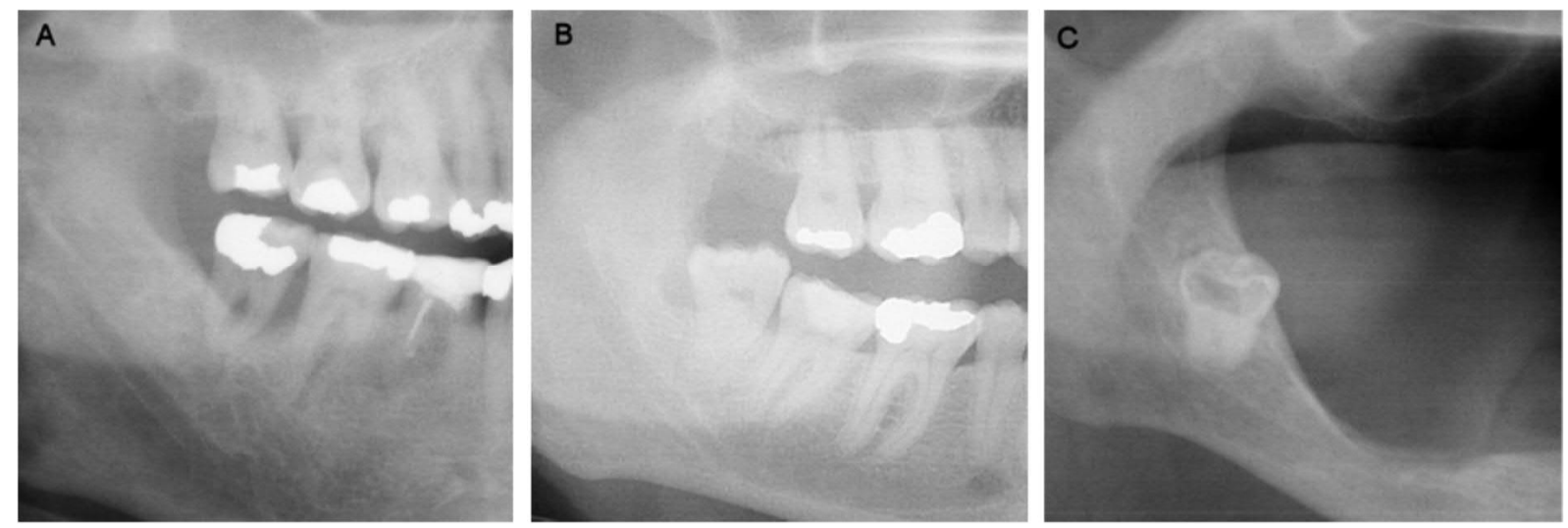

Figure 2.

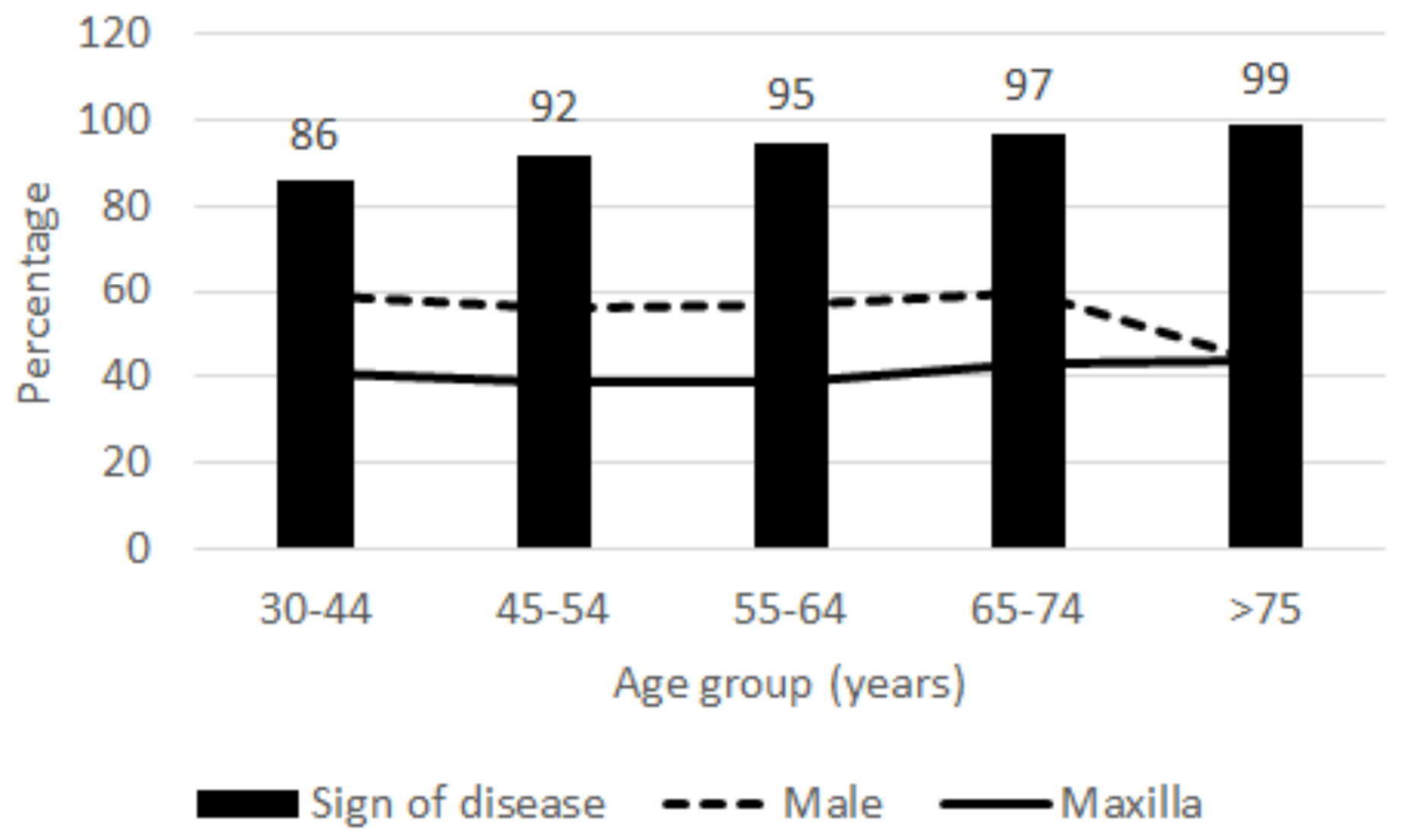

Figure 3. 